\title{
Borgmester August Jørgensen og »den gode sag"
}

\author{
Af Barge L. Barlase.
}

Når man i det historiske mindeår ser tilbage på den lange række af emner, der er behandlet i Sønderjyske Årbøger, kan der være grund til at standse ved de erindringer, som Slesvigs sidste danske borgmester nedskrev i 1906, og som blev trykt samme år under titlen Nogle meddelelser om min embedsvirksomhed $i$ staden Slesvig fra 1856 til 1864 “.

Erindringerne, som er ført i pennen, netop som August Jørgensen $i$ en alder af 81 år påbegyndte sit otium, var egnede til at påkalde den største interesse. Forholdene i Sønderjylland mellem krigene var jo endnu meget mangelfuldt belyst. Her dukkede nu en førsterangs kilde op, og samtidig fik man i hænde et fængslende personligt dokument hidrørende fra en embedsmand, der var blevet en fabel, endnu mens han fungerede, og som i sjalden grad var blevet bagtalt og forhånet af sine modstandere.

Stående „så at sige foran dødens port" siger forfatteren, at han nu „i al beskedenhed frejdigt afventer historiens dom, om den nogensinde gad ulejlige sig med at undersøge min embedsførelse“. Dertil har historien for så vidt ikke fundet sig foranlediget. Et par af hans tjenstlige indberetninger er ganske vist blevet of fentliggjort sammen med andre tilsvarende, og sidst er en snes breve til Regenburg blevet meddelt læseverdenen. ${ }^{1}$ Men derudover har historikerne $\mathrm{i}$ mere end et halvt århundrede kun talt om August Jørgensen en passant.

Når jeg her forsøger en mere indgående behandling, er det ikke detaillerne $\mathrm{i}$ hans embedsførelse, det gælder, men nok så meget manden selv, hans miljø og hans holdning. Dog har jeg følt mig fristet til at uddybe visse træk, som peger indad i byens historie $\mathrm{i}$ hine bevægede år, en periode, der for mange af årbagernes læsere 
vil lede tanken hen på skikkelser som rektor Povelsen, ritmester Sommer, Doris Esselbach, Høyer-Moller m. fl.

*

Thorvald August Brown Jorgensen blev født 6. marts 1825 i Odense. Han var søn af Thorv. Brown, men kom i pleje hos adjunkt Jorgen Vilh. Jørgensen og dennes hustru. Han tilbragte dog de fleste af sine barneår i Nykøbing $\mathrm{Sj}$., idet plejefaderen efter at have giftet sig anden gang fik præstekald her. Fra Odsherred gik vejen til Sorø Akademi, hvorfra August Jørgensen blev student i 1842. Året efter flyttede faderen til Randers som sognepræst (senere provst) ved Skt. Mortens kirke.

Hos den unge student var interessen for jægerlivet tidlig vakt, og det fortjener at nævnes, at han under et feriebesøg i Randers fik lejlighed til at besøge St. St. Blicher i Spentrup og gå på jagt sammen med ham $\mathrm{i}$ heden. August Jørgensen blev med årene selv en jæger af rang, og på sine gamle dage mindedes han tydeligt, hvordan Blicher, der $i$ sine lavloftede små stuer havde været melankolsk og forkuet, tøede op, da de fra en lyngklædt bakkekam betragtede det storlinjede hedelandskab. „Hans ansigt gav hele den strålende klare septemberdag igen i sit lyse, lykkelige smil".3

Ved Treârskrigens udbrud var August Jørgensen godt i gang med et juridisk studium; men han meldte sig straks frivilligt og drog $\mathrm{i}$ felten med "Det beredne jægerkorps for øerne“." I foråret 1849 blev han sat i nummer ved 5 . dragonregiment; men en knæskade, som han havde pådraget sig flere år $i$ forvejen, brod op under feltlivets strabadser, og i januar 1850 blev han hjemsendt." Ian genoptog straks sit afbrudte studium, og efter embedseksamen i 18.51 blev han auditør ved 2. dragonregiment i Holsten." Auditørtjenesten var så godt aflagt, at han kunne stifte hjem og familie, og i 1853 holdt han bryllup med Nicoline Marie Fibiger, en datter af generalmajor Jacob Scavenius Fibiger. ${ }^{7}$ Et års tid efter blev han forfremmet til garnisonsauditør i Rendsborg og kom hurtigt på en venskabelig fod med kommandanten, den navnkundige oberst Helgesen, hvem han mindes som „en markelig mand, der under et fordringsløst, stot og stundom formlost væsen gemte en jernvilje, et ubelvingeligt mod og en sjæelden beskedenhed". 8

Højdepunktet af deres fælles jagtoplevelser var de store, årlige 


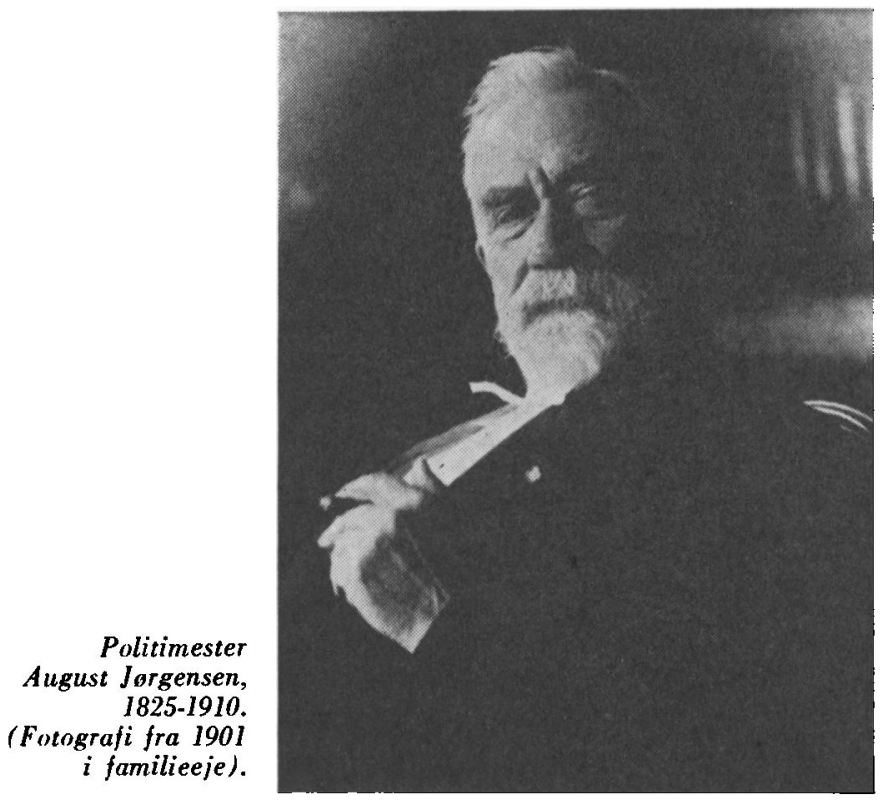

revejagter, som Helgesen foranstaltede i egnen omkring Hollingsted. Ved en enkelt af disse havde en søns fodsel nar lagt sig hindrende $\mathrm{i}$ vejen for August Jorgensens deltagelse; men da den nye verdensborger endelig meldte sin ankomst, skete det så tidligt om morgenen, at faderen kunne drage af sted op ad formiddagen. Han beretter selv om begivenhederne: „Næppe var jeg kommet på plads $i$ et ellekrat, da jeg hørte klapperne i det fjerne, og et øjeblik efter så jeg i hasseltykningen foran mig det på en jagt så sjældne syn af to ræve, der lige $i$ hælene på hinanden styrede ned på mig..... Det var næsten for megen sindsbevægelse på én formiddag "."

Under tjenesten i Rendsborg gav August Jørgensen sig i kast med en opgave, som han allerede under sit sidste semester $i$ hovedstaden var blevet opfordret til at tage op. Han indstillede sig til slesvigsk juridisk eksamen, efter at han tilskyndet af A. F. Kírieger havde sogt tilladelse til at erhverve sig den uden at underkaste sig ny prove i de fag, hvori han tidligere var eksamineret i Kobenhavn. ${ }^{10}$ Eksamen bestod han i 1856, og allerede fjorten 
dage senere modtog han udnævnelse til politimester, auktionarius og rådmand i Slesvig. ${ }^{11}$

Det var under relativt rolige forhold, han begyndte sin virksomhed, så han kunne straks vie sine kræfter til rent praktiske opgaver som reorganisering af byens brandvæsen, vejvedligeholdelse etc. I 1857 lykkedes det ham ved hurtig og prisværdig indgriben at redde det sjældne runemindesmærke, Skardestenen, fra tilintetgørelse. ${ }^{12}$ Året efter døde Helgesen uventet, og da det viste sig, at hans bo var insolvent, satte August Jørgensen sig energisk i bevægelse for at skaffe kreditorerne dækning. Ved Regenburgs bistand lykkedes det at skaffe så mange midler til veje, at vennens gæld kunne indfries. ${ }^{13}$

Derimod voldte samarbejdet $i$ magistraten ham adskillige kvaler. Den bestod foruden ham selv af borgmester C. Leisner, stadssekretær Heinr. Rohweder og rådmændene Joh. Marquardsen og J. H. Hensen. ${ }^{14}$ Det var især forholdet til borgmester Leisner, der gav anledning til gnidninger. August Jørgensen fandt det nødvendigt at anmode det slesvigske ministerium om en forretningsorden, der tilgodeså hans embedsinteresser, og da man ikke uden videre ville imødekomme ønsket, kneb det ham at bevare tålmodigheden.

I brevene til Regenburg lægger han ikke skjul på sin skuffelse. „Er denne situation i længden holdbar for den gode sags skyld?" spørger han i oktober 1858 efter at have talt med minister Wolfhagen på Glücksborg. ${ }^{15}$ "Der bliver aldrig tale om at have hold på byen, så længe Leisner er her". „Det er svært at danse på slap line år ud og år ind, man vader $i$ et uføre af mange slags ondt og har møje med engang imellem at skelne mellem ret og uret", sukker han ved en senere lejlighed efter at have anført, hvordan de øvrige magistratsmedlemmer (,den træske ågerkarl Marquardsen“, „den fordrukne Hensen“ og „den dovne, upålidelige Rohweder") søgte at manøvrere mellem de to antagonister. ${ }^{16}$

Det er et stærkt og temmelig rethaverisk temperament, der ytrer sig i disse breve. Den unge politimester — det må erindres, at han endnu kun var midt $i$ trediverne - var øjensynlig ikke indstillet på at fare med lempe. Han var, som han selv udtrykker det, „fast besluttet på at sætte den gode sag øverst“. Først 
da det var kommet til et ulageligt brud, greb ministeriet ind i konflikten. Forinden var dog situationen i det hele blevet tilspidset som følge af de begivenheder, som gjorde året 1860 så kritisk, såvel på det politiske plan som for August Jørgensen personlig.

Endnu ved juletid 1859 anslâr han $i$ en hilsen til Regenburg det velkendte tema: „Med fastere forhold $i$ den ovre regeringssfære ville man under ellers gunstige omstændigheder kunne fá magt over hele befolkningen." 17 Hvor fjernt var denne situationsbedømmelse ikke fra virkeligheden, netop i Slesvig by! I januar blev der iværksat en målbevidst slesvigholstensk agitation. En petition til stænderforsamlingen hentydede ganske uskrømtet til „de blodige dage fra 1848“ (heraf navnet: de blodige adresser), og et par uger senere forelå den Rumohrske adresse, som bragte de 26 underskrivere i konflikt med statsmyndighederne. ${ }^{18}$

I denne situation traf August Jørgensen to politimæssige foranstaltninger, der skabte voldsomt rore $i$ staden. Han lukkede og forseglede den Heibergske boghandel og anholdt en ung knapmager Gerke, sigtet for at have medvirket ved omdeling af adresserne. Skæbnen ville, at Gerke $i$ et anfald af depression hængte sig i sin celle, og begravelsen gav anledning til omfattende demonstrationer $\mathbf{i}$ gaderne og omkring Michaeliskirkegården. August Jørgensen splittede resolut demonstranterne, idet han satte alt disponibelt mandskab ind og ledede aktionen personlig. ${ }^{10}$

Her må man sande, at det sete afhænger af øjnene, der ser! På dansk hold hilste man undersøgelsen mod adressebevægelsen med tilfredshed. Man trak en parallel til den måde, hvorpả politimester Hammerich i Flensborg samtidig greb sagen an, og for Regenburgs betragtning faldt sammenligningen ud til August Jorgensens fordel. ${ }^{20}$ I modpartens ojne tog Gerke-episoden sig ud som rent hysteri: politimesteren, som var "fanatisk dansksindet og overdrevent religiøs(!) ..... lob ledsaget af sine jagthunde gennem gaderne, som var han hidset af furier!“21

Under den forbitrede stemning, som de to affarer fremkaldte, kunne August Jørgensen ikke undgå at føle sig stærkt tynget af ansvaret. I sine "Meddelelser" hentyder han til „en kortvarig krise" - men det har tjent ham til opmuntring, at han på det tidspunkt havde regeringens fulde tillid.

Wolfhagen havde omsider erkendt, at borgmester Leisner ,ikke 
var egnet til kollegialt samvirke“. Han lod ham forflytte til Eckernförde, og i april blev August Jørgensen udnæevnt til hans efterfolger, efter at han nogen tid forinden havde fảet tildelt ridderkorset. ${ }^{22}$ Da han fortsat skulle beklæede sit politimesterembede, var han altså nu stillet i spidsen for byens hele forvaltning og retspleje. En krævende opgave, som han dog ufortrødent tog op ,.ydmyg, men stærk over for den jammerlige, fejge bagvaskelse", som han udtrykker sig. ${ }^{29}$

Mod slutningen af det begivenhedsrige år skulle der foretages valg til stænderne, og August Jørgensen var ivrigt optaget af sporgsmålet. Han anså det ikke for udelukket, at et halvt hundrede mand med mod til at stemme på en loyal kandidat kunne afgøre valget i Slesvig, og det er interessant at se, hvordan han bedemmer danskhedens eksistensgrundlag: „Kunne vi.... rejse en lille fond på ca. 2000 r., der mod en yderst lav rente gav lån til småhảndværkere, ville vi efterhånden befri mange fra terrorismens kløer. Det er uhyre, hvilken trældom folk her holdes i af de få pengemænd“. Senere kunne han tænke sig „en honnet sparekasse, thi penge, penge, det er nervus rerum". ${ }^{24}$

Som kandidater udpegede man skorstensfejermester Friedr. Sam. Chr. Peschcke og murermester Gustav Jessen jun. Den første tillægger han hverken kundskab eller parlamentarisk evne, men shan har mod og selvstændighed til at vare sin tro bekendt og har alle slesvigeres agtelse". G. Jessen sværmede i 1848 for "det rene, storartede demokrati " og deltog $\mathrm{i}$ "bevxgelsen "; men "han er vendt om og onsker tilslutning til kongeriget og dets institutioner". "Sprogsagen magter han ikke - men han er tilgæengelig for ræson". ${ }^{25}$

Forhåbningerne til valget var som så mange andre bygget på sand. Peschcke fik 22 og Gustav Jessen 15 stemmer. $^{26}$

At August Jørgensen nogen tid efter lod sig forlede til et skridt, som var mindre velovervejet, må ses som en udløber af hine valgforberedelser. I januar 1861 opstillede han en navnefortegnelse omfattende såvel de slesvigholstenske koryfæer som de danske næringsdrivende $\mathrm{i}$ byen. Han sendte den til rektor Povelsen og general Wilster med en følgeskrivelse, hvori han forklarede, at det drejede sig om "de individer, som kongens tro mænd..... har anledning til at vende ryggen“ samt på den anden side „dem, der 


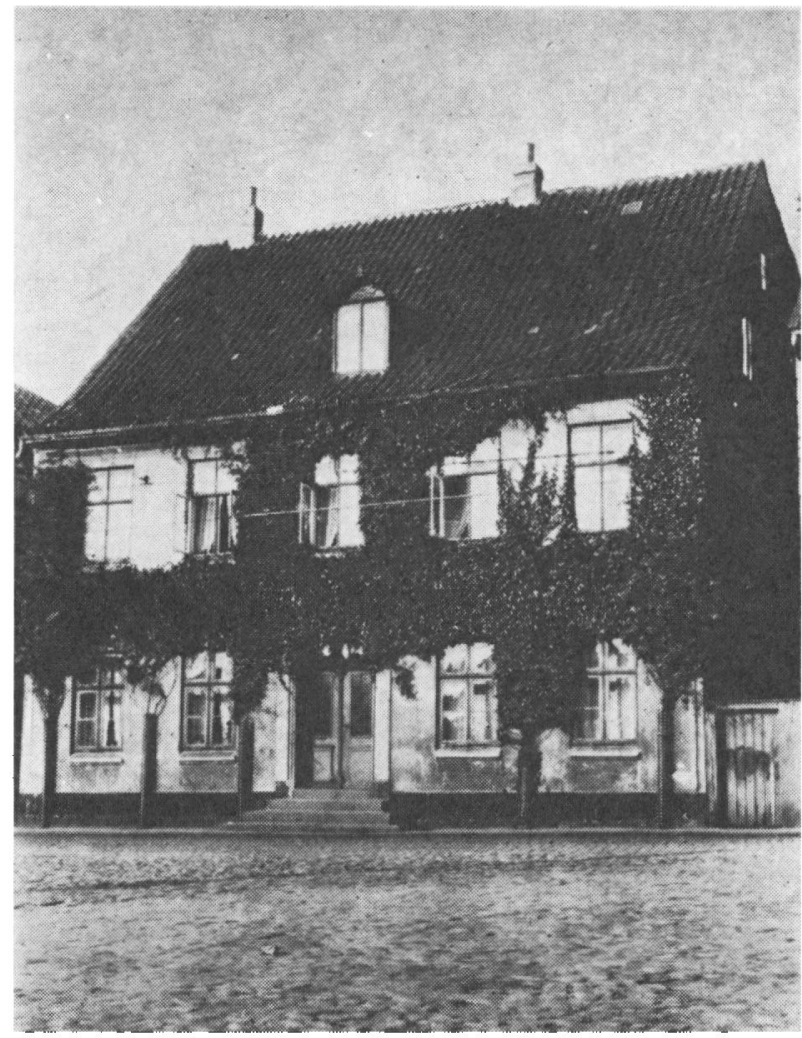

August Jorgensens embedsbolig $i$ Altstadt (Rådhustorvet 16). Fotografi fra 1920'erne.

pâ grund af bevidst loyalt sindelag er genstand for en sådan forfolgelse, at de trænger til særlig understattelse fra de loyales side. “ 27

Ja sagen ved uagtsomhed eller uheld blev bekendt mand og mand imellem, måtte borgmesteren indrykke en erklæring i det lokale blad, hvori han betonede, at det havde drejet sig om en privat meddelelse. $\gg \mathrm{Om}$ nogen vil tillægge mig andre hensigter, står det for hans egen regning, og vedkommende må selv bære ansvaret for noget sådant"..$^{98}$

Rektor Povelsen kommenterede over for Regenburg sagen således: „Politimesterens fremgangsmåde vil upátvivlelig blive gen- 
stand for stærk krilik i København. Skønt jeg ikke ubetinget bifalder formen, anser jeg det dog for min pligt at forsvare den hele fremgangsmåde lige overfor de heftige angreb, der gøres på den, både af vore fjender og vore venner".29

August Jørgensen selv tog jo først til orde mange år senere; men da indrømmede han blankt, at han havde handlet overilet. „Sligt smager af proskription, og jeg betænker mig ikke på åbent at erkende, at jeg dermed har begået et misgreb".30

Det forhindrer dog ikke eftertiden $i$ at betragte de 22 navne på dansksindede personer med al den interesse, der personalhistorisk og nationalt knytter sig til et sâdant aktstykke. Der var tale om folgende:

1. Skorstensfejermester Peschcke

2. Murermester Träuchner

3. Murermester G. Jessen

4. Købmand A. Nielsen

5. Købmand J. Harz

6. Bager H. Chr. Hansen

7. Dbmd., kantor Grewe

8. Slagter Ludv. Caspers

9. Bager A. Wulff

10. Købmand Fehr

11. Møller P. H. Wulff

12. Arbmd. Börensen

13. Kammager Pohlmann

14. Bager Schütz

15. Hyrevognskusk Höpner

16. Arbmd. Soren Petersen

17. Vognmand Joh. Tiedje

18. Maler J. Arlitz

19. Skiferdækker Ahrens

20. Postbud Cordt

21. Skomager $D$. Kierstein

22. Kobmand $H$. Mannings ${ }^{31}$

Året 1860 gik til ende i en ildevarslende atmosfære af usikkerhed og mistro. „Brændingen begynder at gå højt... alle en kommende storms forvarsler er der, og nu behøves et koldt blod ", hed- 


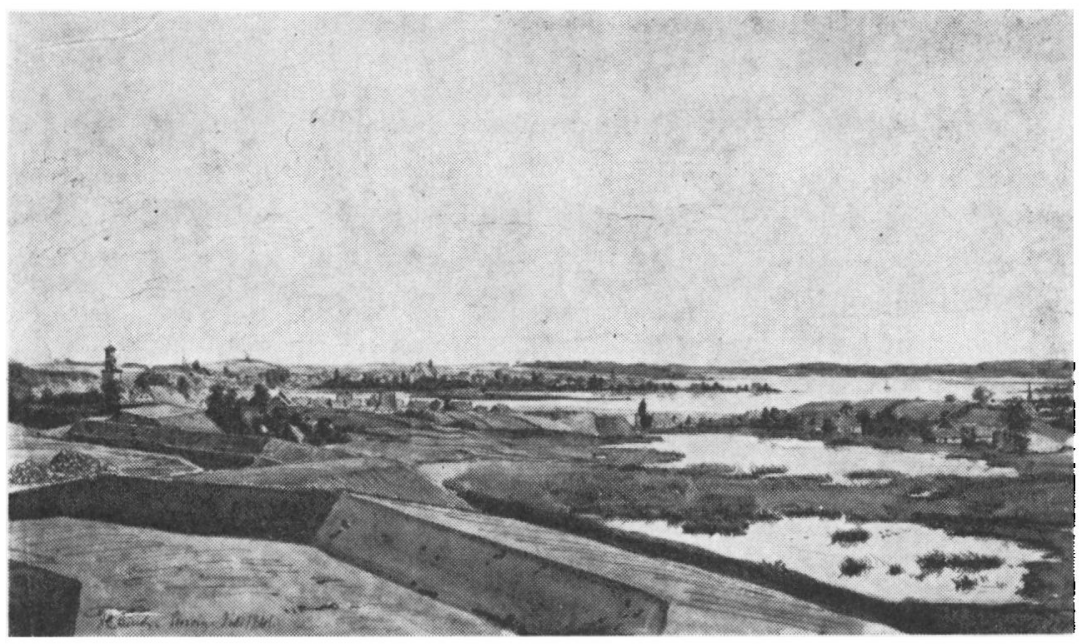

Slesvig og omegn $i$ 1861, her set fra sydvest. I forgrunden en af stiunscrne ted Bustrup. (Farvelagt tegning, F. C. Lund - Det kgl. Bibliotek).

der det i en nytärshilsen til Regenburg. En mánedstid senere forelâ der meddelelse om visse beredskabsforanstaltninger, som regeringen havde truffet. Sligt tillagde August Jorgensen en stærk psykologisk virkning. „De mangfoldige tidligere tilløb, der altid endte med storre tillaggetog, udlxgges som tegn pá swaghed“, havdede han. ${ }^{32}$

Med samme begrundelse modtog han de indrømmelser, der blev givet den slesvigholstenske opposition ved patentet af 9. 1. 1861 med stort forbehold. „Mâtte vi ikke komme til at fortryde emanationen af hine indrømmelser“. "Det er det system, der furer til gamle Danmarks oplosning eller underkastelse under det tyske ag“. "Sydslesvigernes store flertal er tilfredse og lydige, nâr de erfarer, at der skal lystres. “33

Det folgende år, 1862, kan som helhed betragles som et stille for stormen. De kobenhavnske sludentersangeres sommerudflugt til Danevirke og Hütten Bjerge og Frederik 7.'s besøg i oktober har virket oplivende $i$ den danske lejr uden at give anledning til større skarmydsler. ${ }^{34}$ Imens havde August Jørgensen fuldt op at gore med et specielt hverv, der var blevet ham pálagt i 1859 ved 
udnaevnelsen til direktor for dovslummeinstitutlet i Friederichsberg. ${ }^{35}$

Af redegorelsen fra 1906 fremgar det tydeligt, at han onfatfede denne gren af sin virksomhed med særlig interesse. Iler skal blot nevnes, at han ved ansattelse af den fremragende dovstummepaedagogr R. Malling Hansen muliggjorde en undervisning på dansk for elever fra de dansktalende egne af Sonderjylland. Af len tyskuddamnede forstander, Engelke, forlangte han under trussel om bødestraf, at al indgâct korrespondance på dansk fra herlugdommet blev besvaret på dansk, og sidst, men ikke mindst, indledte han en gemnemgribende ombygning efter plan og overslag af arkilekt L. A. Winstrup. ${ }^{36}$

I en cmbedsskrivelse til minister Wolfhagen om bygdeprojeklet fortaller han, at han ogsá har andre jern i ilden: magistraten er enig om en forbedring af borgerskolernes tilstand, og en reform af kommunalvasenet er under forberedelse. ${ }^{37}$ Fra August Jørgensens egen redegørelse ved vi, at også ekspropriationsforretningerne under skanseanlreggene ved Danevirke, konverteringen af byens gæld o.m.a. lâ ham varmt pâ sinde. Man har utvivlsomt lov at hævde, at hans borgmeslerperiode har været præget af både fremsyn og aktivitet. At den også har varet forbundet med en stor arbejdsbyrde folger alene deraf, at han bestandig var underforsynet med kontorhjælp. Det er dette, han hentyder til, når han overfor Wolfhagen indrømmer, at det undertiden kan knibe at følge med: „Vanskeligheden her $\mathrm{i}$ byen er den, at her mangler enhver intelligens og dyglighed, og at man derfor mả gore alt selv, det store med det små. Derfor kommer jeg stundom langsommere al' sted, end jeg onskede". ${ }^{38}$

Samlidig med, at problemerne pá dovstummeinslitullel var rykket sâ staerkt i forgrunden, droftede man vidt og bredt pá byens ulknejper historien om „bindestregen“. En rejsende hândvarkssvend ved navn Kasper Lange fik sit vandrepas konfiskeret, fordi det indeholdt betegnelsen Slesvig-Holsten. Selv blev han laget i forvaring af Jørgensens politi, mens de nærmere omslandigheder blev undersøgt. Sladderen bragte rygtet viden om, og kritikken fik ny næring. ${ }^{39}$

I sommeren 1863 er August Jørgensen - så langt fra at være kørt træt - fuldt optaget af planer om oprettelse af et nyt 
blad i Slesvig. Ideen synes at stamme fra cand jur. J. J. Hansen, alias Jules H., til hvem borgmesteren bl. a. skriver: „Planen vil kumne bidrage til at oprette en af de største forsømmelser, der er begået fra dansk side, nemlig at overlade publikum til den nu eneherskende underkøbte og løgnagtige nordtyske presse." Videre hedder det: „Skulle De støde på den indvending, at der jo er en Flensburger Zeitung, som kan benyttes, da vil jeg sige Dem, at den, der bruger dette argument, ikke må have begreb om, hvor magtesløst et organ bliver, der har nået til en fuldkommen losning af den opgave at kede sine læsere til døde“.40

På August Jørgensens opfordring udarbejdede planens ophavsmand nu et detailleret forslag. Bladet skulle hedde „Südschleswigsche Volkszeitung" og skulle udkomme 2 gange ugentlig i samme format som Itzehoer Nachrichten. Det var tanken, at bladet skulle træde i stedet for Schleswiger Intelligenzblatt, hvis udgiver, frk. Christiani, skulle holdes skadesløs ved en livrente. Jules Hansen ville selv være korrespondent i København, men ville iøvrigt gerne på et senere tidspunkt have sig udgiverprivilegiet tiltransporteret med den københavnske typograf Sædder som mellemmand. ${ }^{41}$

Projejktel nåede aldrig længere end til papiret, velsagtens fordi de skæbnesvangre begivenheder i november: tronskiftet og novemberforfatningens vedtagelse, stillede ministeriet over for mere presserende anliggender.

Det sidst daterede brev fra August Jørgensen til Regenburg er skrevet under indtryk af den voksende krigsfare. Borgmesteren er bekymret for dette og hint, for bevogtningen af Danevirkeskanserne, for gendarmerikorpsets tilstand o.s.v., og han slutter med folgende karakteristiske passus: „Jeg har nogen grund til at frygte, at tidligere djarve og frimodige ytringer har lukket mig ministerens øre.... den stigende bekymring over, hvad jeg ser omkring mig, bevidstheden om, at jeg med koldt blod og sikker dom overser forholdene...... tvang mig til at skrive. At her i byen er udvortes roligt, sålange jeg er i live, er en selvfølge".42

IIans frygt for, at der skulle vare opstået divergenser mellem ham og ministeren, har næppe været helt ubegrundet, hvad der heller ikke undrer, når man tager $i$ betragtning, at han ved en tidligere lejlighed havde ladet ministeren forstå, ,at man i 1 . de- 
partement ikke har begreb om det, man bestyrer". I hvert fald har Wolfhagen på et vist tidspunkt skrevet til ham, at hans „måde at tage tingene på "ikke duede. ${ }^{43}$

Imidlertid drev begivenhederne hastigt imod deres klimaks. Forbitrelsen mod August Jørgensen gav sig bl. a. udtryk i en flom af trusselsbreve, og $i$ de sidste dage af januar fik truslerne et ligefrem makabert islæt, idet en selvbestaltet, sákaldt eksekutivkomite publicerede en dødsdom over ham. ${ }^{44}$ Da der indtrảdte krigstilstand d. 1. februar, lod August Jorgensen i lighed med llere andre embedsmand og officerer sin hustru rejse bort med bornene. Over Iladerslev og Odense gik turen lil Kobenhavn, hvor de tog ophold hos bedstemoderen, general libigers enke. Ilerredsfoged R. Hiort-Lorenzens familie gjorde dem selskab undervejs. ${ }^{4.5}$

August Jørgensen havde tænkt sig at holde ud i sit embede til den bitre ende; men den 4 . februar opgav han dog sit forehavende og forlod Slesvig. Der kom i danske civile og militære kredse nogen forundring til orde over, wat byens højeste civile myndighed forlod sin post "; men man har âbenbart ikke kendt sagens rette sammenhang. ${ }^{46}$ Det var amtmand U. A. v. Holstein, som greb ind, og konsejlspræsident Monrad, som i en samtale med August Jørgensen d. 3. februar befalede ham at tænke på sin egen sikkerhed og på de konsekvenser, som overgreb mod ham kunne få andre steder. Under disse omstæendigheder tog han ikke i betankning at aflevere embedet til sine efterfølgere og følge efter sin familie ud af byen. ${ }^{47}$

Efter nogle ugers afbrydelse kunne hans virketang pa ny lá aflob. Fra 23. marts, indtil fastningen blev rommet 21. april, var han konstitueret som byfoged i Fredericia, ${ }^{48}$ og i de nast folgende: år optrådte han som politiker, idet han valgles til rigsrådets folketing i IIillered, hvor bl.a. pastor (.. Hostrup var stiller for ham. Ved en grundlovsfest 5. juni 1864 talte han om slesvigernes troskab, og to dage senere blev han som eneste kandidat valgt ogsâ til rigsdagens folketing. ${ }^{49}$

Sin politiske virksomhed udsvede han ud fra sine nærmeste forudsætninger: sit patriotiske sindelag, sin juridiske sagkundskab og sine erfaringer fra en meget alsidig forvaltningspraksis i Sles- 
vig. Efter at have stillet en interpellation til krigsministeren fik han sæde $i$ udvalget angående krigens førelse. ${ }^{50}$ Senere deltog han med iver i debatten om ændringer i tyendeloven og forslaget til alm. borgerlig straffelov. ${ }^{51}$ Da det $i$ samlingen 1865-66 drejede sig om ordningen af jurisdiktionsforholdene samt indførelse af kongerigets ret i de fra Slesvig indlemmede distrikter, talte han som ordforer for det folketingsudvalg, der gennemgik lovforslagene..$^{52}$

Under alt dette bevarede han, vel især med Peschcke som mellemmand, nogen føling med udviklingen i den tabte landsdel. Ved et selskab hos $\mathrm{H}$. N. Clausen i november 1865 giver han udtryk for den opfattelse, at stemningen i Sydslesvig blev mere og mere dansk, og at det muligvis var Scheel-Plessen, der udøvede en skjult indflydelse. ${ }^{53}$

Sammen med rigsdagskolleger som tømrermester Kayser og assessor Nyholm ydede han virksom stotte til foreningen Dannebrogs indsamling i kongeriget til hjælp for dansk sprog og folkeliv ${ }^{54}$

I forståelse med Peschcke, Regenburg og D. B. Adler retter han endelig i oktober 1866 henvendelse til Orla Lehmann i dennes egenskab af formand for Den danske Folkeforening for at opnå hjælp til betaling af mulkt og sagsomkostninger for Angler Zeitungs fhv. redaktør. ${ }^{55}$

Et nyt afsnit af August Jørgensens liv tog sin begyndelse, da han i oktober 1866 fik embede som herredsfoged i Lunde-Skam herreder på Fyn. Med bopæl i Odense tog han fortsat del i tidens rørelser, bl. a. som repræsentant for hjælpefonden for fordrevne slesvigere og efter krigsudbruddet i 1870 som medindbyder ved en lokalindsamling til hjolp for de franske sårede. ${ }^{56}$

En sag, der også mâtte have hele hans hjerte, var skytteforeningsbevægelsen. I to perioder, 1870-75 og 1877-1884, beklædte han formandsposten i bestyrelsen for Odense Amts Skytteforening. Det var ham, der fik sagt de forløsende ord under bestræbelserne for at skaffe skytteforeningerne indpas på grevskabet Wedellshorg. ${ }^{57}$ Fra 1875 gav spørgsmålet om Københavns befæstning anledning til stærke politiske brydninger, som i nogen grad belastede hans samarbejde med f. eks. Klaus Berntsen. Det vakte således betydelig opsigt, at August Jørgensen engang i em- 


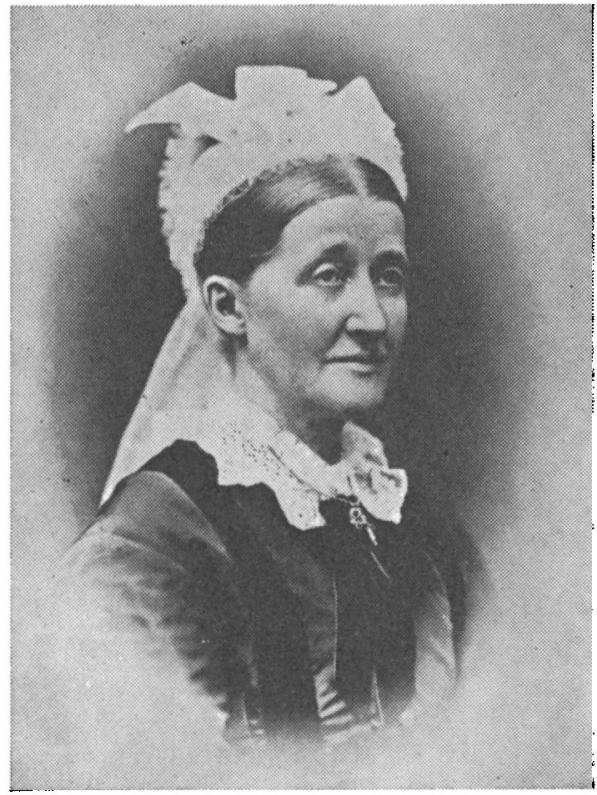

Marie Jorgensen,

f. Fibiger, 1824-1892.

(Fotografi fra 1877

i familieeje).

beds medfør nægtede tilladelse til afholdelse af en skyttefest, hvortil højskoleforstander Jens Lund, Vejstrup, var indbudt som hovedtaler. Det unge venstredemokrati gjorde sig så stærkt gældende på generalforsamlingen i marts 1884, at August Jørgensen blev genvalgt til bestyrelsen med kun 2 stemmers forspring for den kandidat, der fik færrest stemmer. Det bevirkede, at herredsfogden noget fortrydelig trak sig ud af arbejdet i skyttesagens tjeneste. ${ }^{58}$

Slesvig by genså August Jørgensen kun ved én lejlighed. Det var, da han i 1879 deltog i Peschckes begravelse. Fra dette besøg vendte han oplivet hjem og fortalte med åbenbar tilfredshed, at han trods meningsforskelle, sejre og nederlag dog havde modtaget anerkendelse af sit virke som byens borgmester. Han sigtede dermed bl. a. til, at en af byens gamle tysksindede spidsborgere havde sagt til en anden: „Hest du de ohle sehen? Hätten wi de nu mal wedder und könnten all de Preussen in de Slie smitten!"59

Fra 1890 til 1906 var han herredsfoged i Odense herred, hvor han blev hjulpet $i$ embedsforretningerne af sin næstældste søn som 
fuldmægtig. Sine sidste år tilbragte han i København, og ved sin død i 1910 overlevedes han af 6 sønner og 1 datter. ${ }^{60}$

I Fyns Tidendes nekrolog skinner det tydeligt igennem, at han med årene var gledet mere og mere over mod Højre: „Han var i de værste kampår en jævnlig benyttet klubtaler, der tog sig de største friheder over for Venstre. Dertil en udpræget national mand. Om han besad den overlegenhed, som må kunne forudsættes hos en embedsmand $i$ en blandet befolkning, er et andet spørgsmål.“61

August Jørgensen tilhørte det kuld af soranere, som påvirket af P. Hjort og C. F. Wegener var med til at fremme "den gode sag“, danskhedens livsvilje, $i$ tiden mellem krigene. Han var støt forankret $i$ de nationalliberale anskuelser og stod $i$ sprogpolitikken last og brast med den noget ældre skolekammerat Regenburg. I sin holdning til begivenhederne lægger han dog en temmelig unuanceret opfattelse for dagen, og han loddede nappe dybden i de strømninger, der gik gennem den sydslesvigske befolkning. Heri har han vel en del til fælles med adskillige andre, der i tidens løb er kommet til grænselandet nordfra.

Han var uden al tvivl en dygtig administrator og en samvittighedsfuld og initiativrig embedsmand. Man har fra tysk side yndet at fremstille ham som bureaukratisk og smålig. ${ }^{62}$ Det bør dog nok regnes ham til gode, at det var en uriaspost, han var stillet på, og den fanatiske modvilje, der modte ham i Slesvig, skyldes sikkert for en stor del, at man i ham så en årvågen politisk modstander. Selv lagde han visselig ikke fingrene imellem; men han kunne dog på den anden side fuldt ud anerkende modpartens dygtighed og f. eks. samarbejde loyalt med et kommunalt føreremne som fabrikant Firjahn. ${ }^{63}$

Vi gør vel $i$ at mindes August Jørgensen som en markant skikkelse i Sydslesvigs historie, som en varmblodig forkæmper for danskhedens ret og - uanset alt andet - som en nidkær bestyrer af det bysamfund, der var ham betroet lige så længe, som der kunne opretholdes et dansk styre i den gamle by ved Slien. 


\section{NOTER}

1. Da Mag 6. r. III: Stemninger og tilstande i Sønderjylland ved krigens udbrud i 1864. Indberetninger fra embedsmændene. - Da Mag 8. r. I: Breve fra politimester Aug. J. til Regenburg 1857-64.

2. A. Falk-Jensen og H. Hjorth-Nielsen: Candidati og examinati juris 1736-1936 etc., II, 1955. - Wiberg Præstehist.

3. En gammel jægers erindringer, Dansk Jagttidende 1905-06, s. $168 \mathrm{f}$.

4. A. Valentiner: Herregårdsskytterne i 1848, 1898, passim.

5. 5. Dragonregiments stambog og kassationsprotokol. (Hærens arkiv).

6. 2. Dragonregiments korrespondanceprotokol. (Hærens arkiv).

7. Amalie Fibiger: Fibiger, Slægtens ældste etc., 1949, s. 133.

8. Dansk Jagttidende 1906-07, s. 1 ff.

9. Smst. - Sønnen, f. i Rendsborg 21. febr. 1856, er Jørgen Vilh. Jørgensen, $\dagger 1930$ som dommer $i$ Rovse herred.

10. Ansøgning og falgeskrivelse $i$ Regenburgs arkiv (Rigsarkivet). Om Kriegers bestræbelser for at få genindfort de i 1851 givne lettelser for de kobenhavnske juridiske kandidater se Holger Hjelholt: Den danske sprogordning og det danske sprogstyre i Slesvig mellem krigene, 1923, s. 225 ff.

11. A. Falk-Jensen og $\mathbf{H}$. Hjorth-Nielsen: anf. arb.

12. Da Mag 8, r. I, s. 242. - Årbeger for nordisk oldkyndighed og historie 1859 , s. $163 \mathrm{ff}$.

13. Aug. J. til Regenburg 19. okt. 1858 og 20 . novb. 1859, Regenburgs arkiv.

14. Da Mag 8. r. I, s. 244.

15. Aug. J. til Regenburg 19. okt. 1858.

16. Da Mag 8. r. I, s. 246, 251.

17. Smst., s. 253.

18. Asta Heiberg: Erinnerungen aus meinem Leben, 1897, s. $190 \mathrm{ff}$. SJy Hist IV, s. 486 f.

19. SJy Årb 1906, s. 287 ff., jfr. Livs- og krigserindringer, af En gammel Feltpræst, 1894, s. 190.

20. Hist T (Da) 9. r. III, s. 324 .

21. A. Heiberg: Erinnerungen, s. 190 ff.

22. H. R. Hiort-Lorenzen: Erindringer fra Sonderjylland, 1919, s. 29 ff. - Falk-Jensen og Hjorth-Nielsen: anf. arb.

23. Da Mag 8. r. I, s. 256.

24. SJy Årb 1929, s. 173. - Da Mag 8. r. I, s. 257 f.

25. Da Mag 8. r. I, s. 259.

26. Gustav Rasch: Von verlassenem Bruderstamm III, s. 9.

27. Aug. J. til rektor Povelsen 12. jan. 1861, Regenburgs arkiv.

28. Schleswiger Intelligenzblatt 13. febr. 1861.

29. Povelsen til Regenburg 1. febr. 1861, Regenburgs arkiv.

30. SJy Årb 1906, s. 298 .

31. Jfr. SJy Árb 1929, s. 173, hvor der med Itzehoer Nachrichten som kilde foruden 3 af de anforte nævnes en barber Stühr. - Listeus no. 7: Joh. Friedr. Greve, f. 1808 i Elmshorn, kantor i Friedrichsberg, afskediget 1864, derefter lærer ved den danske privatskole $i$ Flensborg til sin dow i 1867 (Tonder Seminarie-Stat).

32. Da Mag 8. r. I, s. 259, 261. 
33. Smst., s. 262.

34. SJy Årb 1929, s. $164 \mathrm{ff}$.

35. Dovstummeinstituttet for hertugdommerne lá på den plads, hvor nu Bugenhagenskolen er rejst (Ernst Schlec: Die Stadt Schleswig in alten Ansichten, 1960, afbildn. no. 94).

36. Aug. Engelke: Die Provinzial-Taubstummenanstalt zu Schleswig 1787 - 1905, 1905, passim. - Ombygningen under Aug. J.s agide er ikke omtalt i Erik Bondo Svanes afhandling om Winstrup (SJy Arb 1946); men tegning, skitser etc. findes i W.'s arkiv (Rigsarkivet).

37. Aug. J. til Wolfhagen, udateret, dog senere end 17. dec. 1862. Regenburgs arkiv.

38. Smst.

39. Iflg. pastor Otto Sommers utrykte erindringer, af hivilke uddrag elskværdigt er meddelt mig af kordegn Otto Vilh. Sommer, Horsens, var der især 2 værtshuse, som Aug. J. holdt et vågent øje med. Det ene var Briinings olstue i Lollfuss, det andet Stehns i Friedrichsberg. - Brünings etablissement var stamknejpe for slibrodrene , jfr. C. N. Schnittger: Erinnerungen eines alten Schleswiger, 1904, s. 187 ff. Et vittighedsblad i Hamburg lancerede en smadevise, hvori det bl. a. hed:
sörgensen, ja also heisst er
ist in Schleswig nämlich Meister
der hochedlen Polizei
und erhebt ein gross' Geschrei *.

Senere, da såvel Aug. J. som hans embedskolleger var fordrevet, var det pågældende blad atter ude efter ham. Denne gang hed det i en mere vulgær tone:
\er Jörgensen sass wie ein Ölgötze da zu den Schleswiger Bürgern Bedrängnis, und als er den harmlosen Bindestrich sah, dann warf er den Mann ins Gefängnis ....

¿Ölgötze er et ukvemsord: fjog, dumrian (C. N. Schnittger: Erinnerungen, s. 304 ff.).

40. Aug. J. til Hansen 20. scpt. 1863, Regenburgs arkiv.

41. Forslaget med yderligere korrespondance som bilag er tilstillet Regenburg og findes $i$ hans arkiv.

42. Da Mag 8. r. I, s. 272.

43. Smst., s. 262.

44. Da Mag 6. r. III, s. 52.

45. Gr Vagt 1932, s. 355 ff.

R. Hiort-Lorenzen: Erindringer, s. 41.

46. R. Hiort-Lorenzen: anf. arb., s. 46.

47. Som politimester konstituerede man herredsfoged $O$. Ries, mens stadssekretær Rathgen (Rohweders eftermand) blev konstitueret i borgmesterembedet. - Amtmand v. Holsteins forestilling og motivering: Da Mag 6. r. III, s. 49. - Monrads fremstilling af begivenheden: Rigsdagstidende 1863-64, Ft. sp. 1020 ff., Lt. sp. 422 ff. I de hektiske dage efter tilbagetoget fra Danevirke hævdedes det, at 
konsejlspræsidenten måtte have haft kendskab til opgivelsen af stillingen, siden han havde opfordret Aug. J. til at forlade byen. Det er dette, der er baggrunden for Monrads udførlige redegørelse. Krieger bemærker 8. febr. $i$ sin dagbog: $\gg M$. giver yderligere forklaringer om Jørgensen, som M. uden tvivl ville have bort om ikke af andre grunde, så for at behage kongen

48. Da Mag 6. r. II, s. 162 og 167. - H. G. Bønnelycke: Minder fra 1864 , s. 67.

49. V. Elberling: Rigsdagens medlemmer gennem hundrede år I, 1949, (m. portræt). - Frederiksborg Amtstidende, 6.-12. juni 1864.

50. Rigsrådstidende, overordentl. saml. 1864, sp. 137-184.

51. Rigsdagstidende $1864-65, \mathrm{Ft}$., passim.

52. Rigsdagstidende 1865-66, Ft., passim.

53. M. P. Bruuns dagbøger 1856-1874, 26. nov. 1865. - Der er tale om baron Carl Scheel-Plessen $(1811$ - 1892), der stod kongehuset ret nær, og som var kendt for sin afvisende holdning overfor augustenborgerne.

54. Chr. F. Monrad til Aug. J. 13. april 1866, Regenburgs arkiv. - Jfr. SJy Årb 1947, s. 117.

55. Aug. J. til Orla Lehmann 16. okt. og 24. okt. 1866. Den danske Folkeforenings arkiv (Rigsarkivet).

56. Aug. J. til D. B. Adler 26. sept. 1870, sidstnæuntes arkiv (Rigsarkivet).

57. Klaus Berntsen: Erindringer fra manddommens år, 1923, s. $159 \mathrm{ff}$.

58. (Samme): Odense Amts Skytteforening gennem 25 år, 1891 s. $40 \mathrm{ff}$.

59. Gr Vagt 1932, s. 355 ff., optegnelser af Aug. J.'s ældste søn, pastor J. Fibiger Jørgensen (1854-1931). Det var den yngre broder, oberst Johs. Jørgensen - Grænseforeningens dygtige sekretær i årene 1920-1931 - som overlod bladet disse erindringer fra Slesvig.

60. Slægtstavle i Amalie Fibiger: anf. arb.

61. Fyns Tidende 21. okt. 1910.

62. Schnittger og Asta Heiberg: anf. arb., jfr. Johs. Lindbæks anmeldelse i SJy Arb. 1910, s. 246.

63. Firjahn, der i marts 1848 var med til at oprette en borgervæbning i byen, var ejer af en læderfabrik i Lollfuss. (E. Schlee: anf. arb., afbildn. 110. - Philippsen: Alt-Schleswig II, s. 202). 